\section{Gender and sexual violence among students at a brazilian university}

\section{Violência de gênero e sexual entre alunos de uma universidade brasileira}

\begin{abstract}
Objectives: the prevalence of gender and sexual violence, its association with gender and ethical attitudes and the experience of suffering and perpetration of violence were evaluated among students at a public university in Brazil.

Methods: a cross-sectional study analyzed the answers given by 2430 students to a questionnaire sent by internet.

Results: among girls, $56.3 \%$ had been subjected to some kind of violence and $9.4 \%$ to sexual violence since university admission; $29.9 \%$ of men reported having perpetrated some kind of violence, $11.4 \%$ gender and $3.3 \%$ sexual violence. Multivariate analysis showed that living with parents/relatives was a protective factor for women being subjected to and men perpetrating sexual violence but not for "any type of violence". Lower scores for ethical attitudes were associated with a greater likelihood of men perpetrating any kind of or gender violence. Student for whom religion was important had a lower risk of being a perpetrator of any type and of sexual violence, but not gender violence.

Conclusions: the findings may be useful for the discussion of this problem and to propose interventions to prevent or minimize the problems of gender and sexual violence on campus. Further studies in other university contexts need to be carried out to increase knowledge and explore possibilities for intervention.
\end{abstract}

Key words Violence against women, Sexual violence, Ethics, Students
Vilma Zotareli 1

Anibal Faúndes 2

Maria José Duarte Osis 3

Graciana Alves Duarte 4

Maria Helena de Sousa 5

Salat Brazil. CEP: 13.084-971. E-mail: zotareli@unicamp.b 2-5 Center for Research on Reproductive Health of Campinas (CEMICAMP).

\title{
Resumo
}

Objetivos: avaliar a prevalência de violência de gênero e sexual e sua associação com atitude de gênero e ética e a experiência de sofrer e perpetrar violência, entre alunos de uma universidade pública no Brasil.

Métodos: estudo transversal que analisou as respostas de 2430 alunos a um questionário enviado por internet.

Resultados: entre as alunas, 56,3\% sofreram algum tipo de violência e 9,4\% sofreram violência sexual desde seu ingresso na universidade; $29,9 \%$ dos homens declararam ter perpetrado algum tipo de violência; $11,4 \%$ violência de gênero e 3,3\% violência sexual. Análise multivariada apontou que viver com pais/parentes foi um fator que protegeu as mulheres de sofrerem e os homens de perpetrarem violência sexual, mas não "qualquer tipo de violência". Baixa pontuação no escore de atitude em ética esteve associada a alta probabilidade dos homens perpetrarem "qualquer tipo de violência" $e$ violência de gênero. Os alunos que davam importância à religião tiveram risco menor de serem perpetradores de "qualquer tipo de violência" e de violência sexual, mas não de violência de gênero.

Conclusões: os achados podem ser úteis para a discussão desse problema e para propor intervenções para prevenir ou minimizar os problemas de violência de gênero e sexual no campus. Além disso, requeremse mais pesquisas para ampliar o conhecimento e as possibilidades de intervenção.

Palavras-chave Violência contra a mulher, Violência sexual, Ética, Estudantes 


\section{Introduction}

Violence is defined as "every act and every idea that reduces an individual to the condition of an object; that violates the internal and external being of a person; that perpetuates social relationships of profound economic, social and cultural inequality". ${ }^{1}$ There are many different forms of violence in society but women are particularly vulnerable to gender and sexual violence. ${ }^{2}$

The effect of violence against women involves society as a whole, since it occurs in almost all environments, even within socially privileged spaces such as universities. Studies conducted in universities in the United States, ${ }^{3}$ Venezuela ${ }^{4}$ and Chile 5 found that a large proportion of students had experienced some form of violence: $44.7 \%$ any form of violence in the USA study; $79 \%$ psychological violence in the Venezuelan universities and $17 \%$ of the female students in the Chilean university experienced unwelcome sexual advances.

A study involving 18 to 21 -year-old male and female students at a university in the city of São Paulo showed that $21.4 \%$ had suffered some type of aggression, psychological violence being the most common, followed by sexual violence, which was more common among women. 6

In view of the need to reduce the current high levels of gender and sexual violence and the fact that social changes usually begin among those with higher levels of education, the aim of the present study was to evaluate the prevalence of gender and sexual violence and to identify the factors that could be associated with the experience of suffering and perpetrating gender and sexual violence, among students at a public university in the state of São Paulo, Brazil.

\section{Methods}

A descriptive, cross-sectional study was carried out among undergraduate and postgraduate students at a university in the state of São Paulo. Data were collected between August and December 2008 using a questionnaire based on the Revised Conflict Tactics Scales as modified by the World Health Organization. 7 The questionnaire was answered online by undergraduate and postgraduate students at a public university in the state of São Paulo using the LimeSurvey free software program (LimeSurvey 1.49RC3). The invitation to participate in the study was sent directly by the university to all regularly enrolled students on three different occasions. The invitation included a link providing access to the questionnaire. Of a total of 23,486 students enrolled at the university, answers were obtained from 2,430, resulting in a response rate of $10.3 \%$.

For the present study, the sample size was calculated as 1,848 subjects based on an estimated overall prevalence of sexual violence of $26 \%, 6$ with an $\alpha$ value of 0.05 and an absolute difference of two percentage points between the sample and population-based estimates.

The dependent variables were:

- "Experience of situations of emotional and physical violence", defined as students reporting having suffered one or more forms of emotional and physical aggression since entering university: having been insulted or made to feel bad about themselves by someone; having been degraded or humiliated in front of others, someone having done something to deliberately frighten or intimidate them, having received threats to hurt them or someone or something they like, having been hit or had something thrown at them that could have hurt them, having been pushed, shaken, punched or struck with an object, kicked, dragged, beaten, strangled or deliberately burned, or threatened with a firearm, knife or any other type of weapon.

- "Experience of situations of sexual violence", defined as students reporting having been subjected to one or more forms of sexual aggression since entering university: having been physically forced to have sexual intercourse against their will; having had sexual intercourse because they were afraid of what the aggressor might do; having had sexual intercourse despite not wanting to because of a belief that it was the aggressor's right; having been forced to subject themselves to a degrading or humiliating sexual act; someone having agreed to use a condom during intercourse but failed to comply with this agreement; someone having refused to use a condom during sexual intercourse.

- "Declaration of having perpetrated emotional and physical violence", defined as students reporting having practiced any of the above-mentioned forms of aggression since admission to the university.

- "Declaration of having perpetrated sexual violence against women", defined as students reporting having practiced any of the abovementioned forms of sexual aggression against women since admission to the university.

- "Declaration of having perpetrated gender violence", defined as reports by male students of having practiced any form of physical, emotional and/or sexual aggression against women since admission to the university.

The independent variables were: attitude towards 
gender, attitude towards ethics, field of study, academic level, age, marital status, skin color, source of income, family income, type of residence, religion and importance given to religion.

The variable "attitude towards gender" referred to the opinion of the research subjects with regard to whether certain activities should only be carried out by women, only by men or by both: cleaning the house, childcare, driving a truck, supporting the family, playing soccer, washing clothes, working outside the home, cooking, governing the country, presiding over a major bank, prevention of sexually transmitted diseases, prevention of pregnancy and deciding when to have sexual intercourse. The answers to these questions generated a score ranging from 0 to 14 points in which every question answered "both" was awarded one point, while either of the other possible answers scored zero.

The variable "attitude towards ethics" referred to the opinion of the subject regarding how acceptable various types of behavior are: cheating in tests, being late for appointments, making fun of other people in class, speaking incessantly without listening, skipping the line at the canteen, skipping class, asking a classmate to sign in for you in class when you are actually absent, littering, jaywalking even when there is a pedestrian-crossing nearby, having your name included in work in which you did not actually participate in, running a red traffic light, riding a bicycle the wrong way up a one-way street, parking your car on a cycle path and copying the answers to test questions from your friends. A score was generated based on the answers to these questions: never -4 points (the most ethically correct attitude); sometimes -3 points; most of the time -2 points; always -1 point; don't know or have no opinion -0 points. Based on the observed median score of 48 , individual scores clustered into two groups of $\geq 48$ points (adequate attitude towards ethics) and $<48$ points (ambiguous or inadequate attitude towards ethics). The categories for place of residence were: university residences, single sex student accommodation / boarding house, mixed sex student accommodation, only with family, and alone. The university residences were used by both male and female students. These are provided by the University and the students live in small houses and are not segregated by sex.

A description of the sample was drawn up using the independent and dependent variables. Subsequently, a bivariate analysis was performed to test the associations between the dependent variables and certain sociodemographic characteristics using the appropriate chi-square test for each domain in the table. ${ }^{8}$ Finally, Poisson's multiple regression analysis for a 5-model adjustment ${ }^{9}$ was performed, presenting the variables that were significantly associated with each one of the dependent variables, the prevalence ratios and their respective $95 \%$ confidence intervals $(95 \% \mathrm{CI})$. Model 1: female students who had been subjected to any type of violence (yes/no); Model 2: female students who had been subjected to sexual violence (yes/no); Model 3: male students who had perpetrated any type of violence (yes/no); Model 4: male students who had perpetrated gender violence (yes/no); and Model 5: male students who had perpetrated sexual violence against women (yes/no). The following independent variables were considered: age (in years), marital status (single/stable union), color (white/non-white), source of income (employed/other; student grant only), family income ( $\leq 5$ minimum salaries/ $>5$ minimum salaries), religion (some/ none), importance given to religion (very important/ other importance or no religion), field of study (exact sciences/ humanities or biological sciences); level (undergraduate/ postgraduate), residence (university dorms or mixed-sex student accommodation/ with family/other), score for attitude towards gender $(<14 ; 14)$, score for attitude towards ethics $(\geq 48$; $<48)$.

This study was in compliance the Brazilian regulations governing studies involving human beings. 10 The research protocol was approved by the internal review board of the University of Campinas.

\section{Results}

The majority of the students were under 25 years of age $(62 \%)$, single $(83 \%)$ and classified themselves as white $(76.5 \%)$. Slightly more than half were male $(51.3 \%) ; 47.7 \%$ lived with their families; $71.6 \%$ were undergraduate students and $54.6 \%$ were enrolled in courses in the field of exact sciences. More than one-third (38.4\%) reported that their source of income was a student grant, while $29 \%$ were in paid employment; $42.4 \%$ declared their family income was over 10 minimum salaries. Twothirds $(66 \%)$ reported belonging to some religion and $42.2 \%$ considered that this was very important in their lives. Around half achieved the maximum score with respect to attitude towards gender $(50.2 \%$ of participants scored 14 points) and most of the others scored 12 or 13 . This variable was therefore not considered for further analysis, as it failed to discriminate as expected. More than half had a score above the median for attitude towards ethics (59.2\% of participants scored 48 points or more) (Table 1). 
More than half of female students $(56.3 \%)$ declared that they had suffered some type of violence (physical, emotional and/or sexual) since entering the university and $9.4 \%$ had suffered sexual violence. Almost 30\% (29.9\%) of the male students declared that they had perpetrated some form of violence since being admitted to the University; $11.4 \%$ reported having perpetrated gender violence, while $3.3 \%$ admitted having perpetrated some form of sexual violence (Data not presented in table).

Female students enrolled in exact sciences courses were less likely to have been subjected to some form of violence than those taking other courses $(51.9 \%$ vs $58.9 \%$; $p=0.024)$. Similarly, female students living with their families were less likely to be subjected to violence than those who lived alone, in a boarding house or other kind of living arrangement (51.9 vs 62.4; $p=0.005$ ) (Table 2).

The percentage of female students who had experienced sexual violence was more than $50 \%$ higher among those who did not have a religious affiliation or did not give great importance to religion ( $p=0.029$ and $p=0.027$, respectively), and graduate students were subjected to sexual violence $50 \%$ more than undergraduate students $(p=0.046)$. On the other hand, the proportion who were subjected to sexual violence was more than twice as high among those who lived in mixed residences (university dormitories or mixed-gender student accommodation) than among those living with their family $(p<0.001)$ (Table 2$)$. Violence against female students since they were admitted to the university was not significantly associated with age, marital status, skin color, employment or family income.

The male students who did not have a religion and those who did not give great importance to religion were one third and 50\% more likely to have perpetrated some form of violence compared to the others ( $p=0.002$ and $p<0.001$, respectively). A greater proportion of undergraduate students declared having perpetrated some form of violence compared to postgraduate students $(p=0.043)$. Likewise, the proportion of students who had perpetrated some form of violence was greater among those living in university dormitories or in mixedsex student accommodation, whereas those living with their families were less likely to have perpetrated violence $(p=0.001)$. The risk of being a perpetrator of some form of violence was almost $70 \%$ higher among students with a score that reflected a less adequate attitude towards ethics compared to those with a score of $>48(p=0.001)$ (Table 3$)$.

The proportion of perpetrators of gender violence was almost twice as high among students of biological sciences or humanities compared with those studying exact sciences $(p<0.001)$. Living in mixed-sex student accommodation was a factor associated with more than twice the likelihood of being a perpetrator of gender violence $(p<0.001)$ as compared with students living with their families. The risk of being a perpetrator of this type of violence was almost twice as high among students with a score reflecting a less adequate attitude towards ethics compared to those with a score of $>48$ $(p=0.001)$. Having a religion and the importance given to religion were not associated with being a perpetrator of gender violence.

Having a religion was also not associated with perpetrating sexual violence, but students who did not give great importance to religion were almost 4 times more likely to be perpetrators of sexual violence against women $(p=0.004)$. Students living in mixed-sex residences were almost 6 times more likely, whereas those in other forms of accommodation were 3 times more likely to be perpetrators of this form of violence, as compared with those living with their family (Table 3 ).

Multiple regression analysis did not identify variables significantly associated with female students having been subjected to any form of violence (Table 4). With respect to having been subjected to sexual violence, the type of residence in which the girls lived was associated with this event $(\mathrm{PR}=2.85$; 95\%CI: $1.74-4.69$ for university accommodation/mixed-sex student accommodation). Academic level was also found to be associated with having been subjected to sexual violence $(\mathrm{PR}=1.62$; 95\%CI: $1.03-2.53$ for postgraduate students compared to undergraduates).

Admission by the students that they had perpetrated some form of violence was more frequent among those who declared not being religious or who considered religion to have little or no importance $(\mathrm{PR}=1.46 ; 95 \% \mathrm{CI}: 1.08-1.96)$; among those studying humanities or biological sciences $(\mathrm{PR}=$ 1.31; 95\%CI: $1.00-1.70)$; among those scoring $<48$ in the evaluation of their attitude towards ethics $(\mathrm{PR}=1.65$; 95\%CI: 1.27-2.14); and among those living in university accommodation or mixed-sex student accommodation $(\mathrm{PR}=1.49$; 95\% CI: 1.10 2.02). Having perpetrated gender violence was associated with lower scores in the evaluation of students' attitude towards ethics $(\mathrm{PR}=2.25 ; 95 \% \mathrm{CI}$ : 1.45-3.49); with studying the humanities or biological sciences $(\mathrm{PR}=2.14 ; 95 \% \mathrm{CI}: 1.42-3.24)$; and with living in university accommodation/mixed-sex student accommodation $(\mathrm{PR}=2.17 ; 95 \% \mathrm{CI}$ : 1.38 $3.40)$. The practice of sexual violence against 
women was associated with living in university accommodation/mixed-sex student accommodation $(\mathrm{PR}=3.27$; 95\%CI: $1.54-6.93)$ and not being reli- gious or considering religion to be of little or no importance $(\mathrm{PR}=4.48 ; 95 \% \mathrm{CI}$ : $1.35-14.81)$.

\section{Table 1}

\begin{tabular}{|c|c|c|}
\hline Variable & $\mathbf{N}$ & $\%$ \\
\hline \multicolumn{3}{|l|}{ Sex } \\
\hline Male & 1228 & 51.0 \\
\hline Female & 1167 & 49.0 \\
\hline \multicolumn{3}{|l|}{ Age (years) } \\
\hline$<25$ & 1409 & 62.0 \\
\hline$\geq 25$ & 862 & 38.0 \\
\hline \multicolumn{3}{|l|}{ Marital status } \\
\hline Single & 1985 & 83.0 \\
\hline Ever married or in a stable union & 405 & 17.0 \\
\hline \multicolumn{3}{|l|}{ Color } \\
\hline White & 1796 & 76.5 \\
\hline Other & 553 & 23.5 \\
\hline \multicolumn{3}{|l|}{ Source of income } \\
\hline Employed & 684 & 29.0 \\
\hline Receives student grant & 902 & 38.4 \\
\hline Other & 997 & 42.0 \\
\hline \multicolumn{3}{|l|}{ Family income (minimum salaries) } \\
\hline$\leq 5$ & 554 & 25.4 \\
\hline Between 5 and 10 & 704 & 32.2 \\
\hline$>10$ & 926 & 42.4 \\
\hline \multicolumn{3}{|l|}{ Religion } \\
\hline Some & 1507 & 66.0 \\
\hline None & 784 & 34.0 \\
\hline \multicolumn{3}{|l|}{ Importance given to religion } \\
\hline Very important & 978 & 42.2 \\
\hline Other importance & 536 & 23.3 \\
\hline No religion & 784 & 34.1 \\
\hline \multicolumn{3}{|l|}{ Field of study } \\
\hline Biological sciences & 464 & 19.4 \\
\hline Exact sciences & 1304 & 54.6 \\
\hline Humanities & 618 & 27.1 \\
\hline \multicolumn{3}{|l|}{ Level } \\
\hline Undergraduate & 1708 & 71.6 \\
\hline Postgraduate & 678 & 28.4 \\
\hline \multicolumn{3}{|l|}{ Residence } \\
\hline University accommodation & 135 & 5.7 \\
\hline Single-sex student accommodation/boarding house & 625 & 26.3 \\
\hline Mixed-sex student accommodation & 203 & 8.5 \\
\hline Only with family & 1134 & 47.7 \\
\hline Alone & 298 & 12.5 \\
\hline \multicolumn{3}{|l|}{ Score for attitude towards gender } \\
\hline$<14$ & 1184 & 50.0 \\
\hline 14 & 1174 & 49.7 \\
\hline \multicolumn{3}{|l|}{ Score for attitude towards ethics } \\
\hline$<48$ & 939 & 40.8 \\
\hline$\geq 48$ & 1363 & 59.2 \\
\hline
\end{tabular}

* Data missing for 159 students with respect to age; 35 for sex; 81 for color; 28 for religion, 38 for marital status (2 gave other answers); 79 for source of income; 244 for family income (2 gave other answers); 99 for religion; 114 for importance given to religion (18 gave other answers); 72 for gender score and 128 for ethics score. 
Percentage of female students who had experienced violence according to sociodemographic variables.

\begin{tabular}{|c|c|c|c|c|c|c|}
\hline \multirow[t]{2}{*}{ Variables } & \multicolumn{3}{|c|}{ Experienced any form of violence } & \multicolumn{3}{|c|}{ Experienced sexual violence } \\
\hline & $\%$ & $\mathrm{n}$ & $p$ & $\%$ & $\mathrm{n}$ & $p$ \\
\hline \multicolumn{7}{|l|}{ Age (years) } \\
\hline$<25$ & 55.7 & 663 & 0.410 & 8.4 & 652 & 0.247 \\
\hline$\geq 25$ & 58.4 & 423 & & 10.7 & 419 & \\
\hline \multicolumn{7}{|l|}{ Marital status } \\
\hline Single & 56.4 & 908 & 0.952 & 9.7 & 895 & 0.539 \\
\hline Ever in a stable union & 55.9 & 213 & & 8.1 & 211 & \\
\hline \multicolumn{7}{|l|}{ Color } \\
\hline White & 55.9 & 868 & 0.389 & 9.7 & 855 & 0.890 \\
\hline Other & 59.3 & 231 & & 9.1 & 230 & \\
\hline \multicolumn{7}{|l|}{ Source of income } \\
\hline Employed & 55.9 & 322 & 0.021 & 8.4 & 321 & 0.811 \\
\hline Student grant & 61.2 & 430 & & 9.7 & 424 & \\
\hline Other & 51.3 & 349 & & 9.6 & 343 & \\
\hline \multicolumn{7}{|l|}{$\begin{array}{l}\text { Family income (minimum } \\
\text { salaries) }\end{array}$} \\
\hline$\leq 5$ & 58.6 & 263 & 0.731 & 10.7 & 262 & 0.143 \\
\hline$>5$ and $\leq 10$ & 55.4 & 336 & & 7.3 & 327 & \\
\hline$>10$ & 57.1 & 429 & & 11.4 & 428 & \\
\hline \multicolumn{7}{|l|}{ Religion } \\
\hline Some & 54.4 & 777 & 0.085 & 8.2 & 765 & 0.029 \\
\hline None & 60.4 & 313 & & 12.8 & 313 & \\
\hline \multicolumn{7}{|c|}{ Importance given to religion } \\
\hline Very important & 54.8 & 542 & 0.246 & 7.1 & 538 & 0.023 \\
\hline Other importance & 54.9 & 224 & & 8.8 & 216 & \\
\hline No religion & 60.4 & 313 & & 12.8 & 313 & \\
\hline \multicolumn{7}{|l|}{ Field of study } \\
\hline Exact sciences & 51.8 & 419 & 0.024 & 7.5 & 414 & 0.163 \\
\hline Other areas & 58.9 & 696 & & 10.2 & 687 & \\
\hline \multicolumn{7}{|l|}{ Level } \\
\hline Undergraduate & 55.0 & 756 & 0.265 & 7.9 & 746 & 0.046 \\
\hline Postgraduate & 58.8 & 359 & & 11.8 & 355 & \\
\hline \multicolumn{7}{|l|}{ Residence } \\
\hline With family & 51.9 & 555 & 0,002 & 7.2 & 553 & 0.026 \\
\hline Other/alone & 61.4 & 521 & & 11,4 & 510 & \\
\hline
\end{tabular}


Percentage of students who were perpetrators of violence, considering sociodemographic variables and scores on gender/ethics attitudes.

\begin{tabular}{|c|c|c|c|c|c|c|c|c|c|}
\hline \multirow[t]{2}{*}{ Variables } & \multicolumn{3}{|c|}{$\begin{array}{l}\text { Perpetrated any form } \\
\text { violence }\end{array}$} & \multicolumn{3}{|c|}{$\begin{array}{l}\text { Perpetrated gender } \\
\text { violence }\end{array}$} & \multicolumn{3}{|c|}{$\begin{array}{l}\text { Perpetrated sexual violence of } \\
\text { against women }\end{array}$} \\
\hline & $\%$ & $\mathrm{n}$ & $p$ & $\%$ & $\mathrm{n}$ & $p$ & $\%$ & $\mathrm{n}$ & $p$ \\
\hline \multicolumn{10}{|l|}{ Age (years) } \\
\hline$<25$ & 31.6 & 671 & 0.223 & 10.7 & 671 & 0.328 & 3.5 & 683 & $>0.999$ \\
\hline$\geq 25$ & 27.8 & 395 & & 12.9 & 395 & & 3.5 & 402 & \\
\hline \multicolumn{10}{|l|}{ Marital status } \\
\hline Single & 30.5 & 974 & 0.430 & 11.7 & 974 & 0.419 & 3.4 & 994 & 0.887 \\
\hline $\begin{array}{l}\text { In a stable union/was in a stable } \\
\text { union at some time }\end{array}$ & 27.2 & 173 & & 9.2 & 173 & & 2.9 & 174 & \\
\hline \multicolumn{10}{|l|}{ Color } \\
\hline White & 30.2 & 843 & 0.811 & 11.2 & 843 & 0.709 & 3.0 & 857 & 0.504 \\
\hline Other & 29.3 & 287 & & 12.2 & 287 & & 4.1 & 295 & \\
\hline \multicolumn{10}{|l|}{ Source of income } \\
\hline Employed & 31.3 & 336 & 0.228 & 12.5 & 336 & 0.071 & 3.6 & 333 & 0.901 \\
\hline Student grant only & 32.6 & 402 & & 13.7 & 402 & & 3.4 & 417 & \\
\hline Other & 27.2 & 390 & & 8.7 & 390 & & 3.0 & 399 & \\
\hline \multicolumn{10}{|l|}{ Family income (minimum salaries) } \\
\hline$\leq 5$ & 25.9 & 255 & 0.115 & 10.2 & 255 & 0.287 & 1.9 & 265 & 0.221 \\
\hline$>5$ and $\leq 10$ & 28.8 & 340 & & 8.8 & 340 & & 3.8 & 339 & \\
\hline$>10$ & 33.0 & 457 & & 12.3 & 457 & & 4.1 & 463 & \\
\hline \multicolumn{10}{|l|}{ Religion } \\
\hline Some & 26.2 & 691 & 0.002 & 10.1 & 691 & 0.111 & 2.8 & 710 & 0.214 \\
\hline None & 35.2 & 432 & & 13.4 & 432 & & 4.4 & 434 & \\
\hline \multicolumn{10}{|l|}{ Importance given to religion } \\
\hline Very important & 22.5 & 395 & $<0.001$ & 9.4 & 395 & 0.180 & 1.2 & 406 & 0.005 \\
\hline Other importance & 32.5 & 292 & & 11.0 & 292 & & 5.0 & 302 & \\
\hline No religion & 35.2 & 432 & & 13.4 & 432 & & 4.4 & 434 & \\
\hline \multicolumn{10}{|l|}{ Field of study } \\
\hline Exact sciences & 28.6 & 812 & 0.118 & 9.0 & 812 & $<0.001$ & 3.1 & 830 & 0.663 \\
\hline Other areas & 33.4 & 335 & & 17.6 & 335 & & 3.8 & 338 & \\
\hline \multicolumn{10}{|l|}{ Level } \\
\hline Undergraduate & 31.6 & 860 & 0.043 & 11.2 & 860 & 0.598 & 3.2 & 875 & 0.788 \\
\hline Postgraduate & 25.1 & 287 & & 12.5 & 287 & & 3.8 & 293 & \\
\hline \multicolumn{10}{|l|}{ Residence } \\
\hline With family & 23.8 & 425 & $<0.002$ & 7.8 & 425 & 0.005 & 1.2 & 434 & 0.005 \\
\hline Other/alone & 33.8 & 681 & & 13.5 & 681 & & 4.3 & 692 & \\
\hline \multicolumn{10}{|l|}{ Score for attitude towards gender } \\
\hline$<14$ & 31.0 & 664 & 0.230 & 11.9 & 664 & 0.539 & 3.6 & 675 & 0.545 \\
\hline 14 & 27.5 & 465 & & 10.5 & 465 & & 2.7 & 475 & \\
\hline \multicolumn{10}{|l|}{ Score for attitude towards ethics } \\
\hline$<48$ & 38.2 & 531 & $<0.001$ & 15.3 & 531 & $<0.001$ & 4.2 & 542 & 0.157 \\
\hline$\geq 48$ & 22.7 & 582 & & 8.2 & 582 & & 2.5 & 589 & \\
\hline
\end{tabular}


Variables associated with female students having been subjected to or male students having perpetrated violence (Poisson's analysis).

\begin{tabular}{|c|c|c|c|}
\hline Dependent variables & PR & $95 \% \mathrm{Cl}$ & $p$ \\
\hline \multicolumn{4}{|l|}{ Model $1(n=862)$} \\
\hline $\begin{array}{l}\text { Female students who had experienced } \\
\text { any type of violence }\end{array}$ & \multicolumn{2}{|c|}{ No associated variables } & \\
\hline \multicolumn{4}{|l|}{ Model $2(n=853)$} \\
\hline \multicolumn{4}{|l|}{ Female students who had been } \\
\hline \multicolumn{4}{|l|}{ subjected to sexual violence } \\
\hline \multicolumn{4}{|l|}{ Residence: } \\
\hline With family & 1.00 & - & - \\
\hline Others/alone & 1.71 & $1.10-2.66$ & 0.018 \\
\hline \multicolumn{4}{|l|}{ Model $3(n=815)$} \\
\hline \multicolumn{4}{|l|}{ Students who had perpetrated } \\
\hline \multicolumn{4}{|l|}{ any type of violence } \\
\hline \multicolumn{4}{|l|}{ Score for attitude towards ethics: } \\
\hline$<48$ & 1.00 & - & - \\
\hline$\geq 48$ & 0.59 & $0.45-0.77$ & $<0.001$ \\
\hline \multicolumn{4}{|l|}{ Importance given to religion: } \\
\hline A lot & 1.00 & - & - \\
\hline Other/no religion & 1.47 & $1.10-1.98$ & 0.010 \\
\hline \multicolumn{4}{|l|}{ Field of study: } \\
\hline Exact sciences & 1.00 & - & - \\
\hline Humanities/biological sciences & 1.33 & $1.02-1.73$ & 0.035 \\
\hline \multicolumn{4}{|l|}{ Model $4(n=815)$} \\
\hline \multicolumn{4}{|l|}{ Students who perpetrated } \\
\hline \multicolumn{4}{|l|}{ gender violence } \\
\hline \multicolumn{4}{|l|}{ Score for attitude towards ethics: } \\
\hline$<48$ & 1.00 & - & - \\
\hline$\geq 48$ & 0.41 & $0.26-0.63$ & $<0.001$ \\
\hline \multicolumn{4}{|l|}{ Field of study: } \\
\hline Exact sciences & 1.00 & - & - \\
\hline Humanities/biological sciences & 2.17 & $1.44-3.28$ & $<0.001$ \\
\hline \multicolumn{4}{|l|}{ Source of income: } \\
\hline Employed & 1.00 & - & - \\
\hline Student grant & 1.55 & $1.03-2.34$ & 0.038 \\
\hline \multicolumn{4}{|l|}{ Model $5(n=826)$} \\
\hline \multicolumn{4}{|l|}{ Male students who perpetrated } \\
\hline \multicolumn{4}{|l|}{ sexual violence against women } \\
\hline \multicolumn{4}{|l|}{ Residence: } \\
\hline With family & 1.00 & - & - \\
\hline Other/alone & 3.63 & $1.26-10.44$ & 0.017 \\
\hline \multicolumn{4}{|l|}{ Importance given to religion: } \\
\hline A lot & 1.00 & - & - \\
\hline Other/no religion & 4.23 & $1.28-14.01$ & 0.018 \\
\hline
\end{tabular}

PR: prevalence ratio; $95 \% \mathrm{Cl}: 95 \%$ confidence interval.

\section{Discussion}

Violence in all its forms is pandemic all around the world and affects the lives of practically everyone, even those with good economic resources, as is generally the case among Brazilian public university 
students. The results of this study confirm that the University environment is far from being free of different forms of violence, as more than half of the female students reported having been subjected to some form of violence and one tenth had been subjected to sexual violence since entering the university. On the other hand, almost one third of the male university students admitted having been perpetrators of some form of violence. These data are in agreement with findings of other studies in deve-loped and developing countries, which show levels of violence not very different from those found in this study, varying between 45 and $21 \%$ for general violence and 17 and $1 \%$ for sexual violence reported by female students. ${ }^{3-6}$

Having or not a religion affiliation was not associated with being or not being an aggressor, while giving great importance to any religion was strongly associated with a lower likelihood of being a perpetrator of any form of violence or sexual violence, both in the univariate and multivariate analysis. This confirms other studies showing that religion itself did not provoke change in individual behavior regarding any kind of violence, while it suggests that the relevance given to religion in the individual's life potentially interferes in their moral conduct to the extent implied by an association with "morally concerned" divinities as in various branches of Christianity and Buddhism, among 18 others. 11 Although the social role of religion is questioned today, it seems that it still exerts a strong influence on the construction of meanings for individuals and groups. In the specific case of young people, it has been perceived to constitute a significant point of reference as an environment of sociability, as a background against which they view their beliefs and experiences or even as a reference for everything that they do not want for themselves. The lack of association of importance given to religion with gender violence was to be expected, since religions generally are not known for promoting gender equality. 12

Having a lower score for ethical values was associated with a greater likelihood of perpetrating any form of violence and gender violence, but not sexual violence, in particular, according to both univariate and multivariate analysis. It is interesting to note that, while the item better ethical principles was associated with less general and gender aggression it was not associated with less sexual violence. We do not have a valid hypothesis to explain this.

On the other hand, it was not surprising that living with one's family provided protection both from being subjected to and from perpetrating sexual violence. The direct influence of the family seems to regulate sexual behavior, 13,14 while it did not seem to have the same influence over the likelihood of either being subjected to or perpetrating other forms of violence. This last finding contrasts with other studies, suggesting that proximity to the family is a protective factor against delinquency and violent behavior. 15,16 The apparent discrepancy with our results may be explained by the relative mildness of the violence practiced by the students in our sample. On the other hand, the association between close family contact and less sexual violence is in line with studies showing that young males who perpetrate sexual violence are more likely to have a conflictual relationship with their fathers. ${ }^{17}$

We have no firm hypothesis to explain the finding that being a student of some form of exact science was a protective factor for being an aggressor in general or perpetrator of gender violence. This may be connected with the characteristics of students who choose such disciplines in contrast with those who prefer social or biological sciences. It may also be related to the habit of more intensive social activities at night among the latter group compared to those studying exact sciences.

Finally, the greater proportion of gender aggressors among students living in a university fellowship is not easy to explain and was a surprising finding. One possible hypothesis is that it may be a reaction to their economic dependence, whereby gender violence could be used as a form of self-affirmation, as a means of maintaining control over the social environment, taking advantage of the traditional belief that women are fragile and easy to submit to male domination. 18

The limitations of the present study resulting from the response rate obtained, a little over $10 \%$, must be taken into consideration. The study sample cannot be considered representative of the overall population of university students in question. Nevertheless, when the characteristics of the sample were compared with those of the university population, there was a statistically significant difference only with respect to age and the field of study. The present sample was composed of younger students and a greater proportion was taking courses in the field of exact sciences, while a smaller proportion was studying biological sciences compared to the total population of possible respondents. In the analyses performed for this paper, age was not associated with any of the dependent variables; therefore, it is unlikely that this difference between the sample and the overall universe of students could have led to any bias in the findings. Nevertheless, there were 
differences with respect to the field of study, since the students of exact sciences were those that had experienced and perpetrated violence the least. It is reasonable to suppose that, if the number of students from other fields who responded was proportional to the number of students enrolled, all the percentages of violence found could increase. In other words, a selection bias may exist and it is possible that the actual rates of violence are greater than those identified in the study sample. However, all this does not invalidate the associations between several variables and the experience of having been subjected to or perpetrated violence, as identified in this study.

Furthermore, despite these limitations, the present findings corroborate the existing literature and may be useful in promoting discussions of this important problem and suggesting areas in which it may be possible to intervene within university environments to prevent or minimize gender and sexual violence. It is, however, clear that further studies in other university contexts need to be carried out in order to increase available knowledge and the possibilities for intervention.

\section{Acknowledgments}

We are thankful to Fundação de Amparo à Pesquisa do Estado de São Paulo (FAPESP), State University of Campinas (Unicamp) and CEMICAMP for their support and assistance.

\section{References}

1. Chauí M. Ética e violência. Teoria e Debate [on line]. 1998: 39. [accessed Apr 4 2008]. Available from: http://www2.fpa.org.br/portal/modules/news/article.php?st oryid $=2305$

2. Carrara S, Sarti C. Apresentação. Physis. 2006; 16: 163-6.

3. Forke CM, Myers RK, Catallozzi M, Schwarz DF. Relationship violence among female and male college undergraduate students. Arch Pediatr Adolesc Med. 2008; 162: 634-41

4. Martinez LW. Rompiendo el silencio: del remanso romántico a la agitación de una violencia inesperada. Fermentum [on line]. 2006; 16: 607-40. [accessed July 5 2007]. Available from: http://www.saber.ula.ve/cgi-win/be_alex. exe?Acceso $=$ T016300003482/3

5. Lehrer JA, Lehrer VL, Lehrer EL, Oyarzún PB. Prevalence of and risk factors for sexual victimization in college women in Chile. Int Fam Plan Perspect. 2007; 33: 168-75.

6. Aldrighi T. Prevalência e cronicidade da violência física no namoro entre jovens universitários do Estado de São Paulo - Brasil. Psicol Teor Prát. 2004; 6: 105-20.

7. WHO (World Health Organization). WHO multi-country study on women's health and domestic violence against women. Initial results on prevalence, health outcomes and women's responses. Geneva; 2005.

8. Altman DG. Practical statistics for medical research. Boca Raton: Chapman \& Hall/CRC; 1999.

9. Barros AJ, Hirakata VN. Alternatives for logistic regression in cross-sectional studies: an empirical comparison of models that directly estimate the prevalence ratio. BMC Med Res Methodol. 2003; 3: 21.

10. Brasil. Ministério da Saúde. Conselho Nacional de Saúde. Resolução 196/96 sobre pesquisa envolvendo seres humanos. Bioética. 1996; 4: 15-25.

11. Stark R. Gods, rituals and the moral order. J Sci Study Religion. 2001; 40: 619-36.

12. Bracke S. Conjugating the modern/ religious, conceptualizing female religious agency: contours of a 'post-secular' conjuncture. Theor Cult Soc. 2008; 25: 51-67.

13. Lehrer JA, Lehrer VL, Lehrer EL, Oyarzún PB. Prevalence of and risk factors for sexual victimization in college women in Chile. Int Fam Plann Persp. 2007; 33: 168-75.

14. Anacleto AJ, Njaine K, Longo GZ, Boing AF, Peres KG. Prevalência e fatores associados à violência entre parceiros íntimos: um estudo de base populacional em Lages, Santa Catarina, Brasil, 2007. Cad Saúde Pública. 2009; 25: 800-8.

15. Bahr SJ, Maugham SL, Marcus AC, Li B. Family, religiosity, and the risk of adolescent drug use. J Marriage Fam. 1998; 60: 979-92.

16. Howard D, Qiu Y, Boekeloo B. Personal and social contextual correlates of adolescent dating violence. J Adolesc Health. 2003; 33: 9-17.

17. Adams-Curtis LE, Forbes GB. College women's experiences of sexual coertion: a review of cultural, perpetrator, victim, and situational variables. Trauma Violence Abuse. 2004; 5: 91-122.

18. Brandon M, Smithey M. The effects of academic and interpersonal stress on dating violence among college students: a test of classical strain theory. J Interpers Violence [on line] 2011. [accessed fev 5 2012]. Available from: http://jiv.sagepub.com/content/early/2011/09/21/08862605 11423257

Recebido em 1 de novembro de 2011

Versão final apresentada em 10 de janeiro de 2012

Aprovado em 8 de fevereiro de 2012 